\title{
THE MONETARY ECONOMY AND THE ECONOMIC CRISIS*
}

\author{
DAVID LAIDLER
}

CHOPE Working Paper No. 2011-04

January 2011

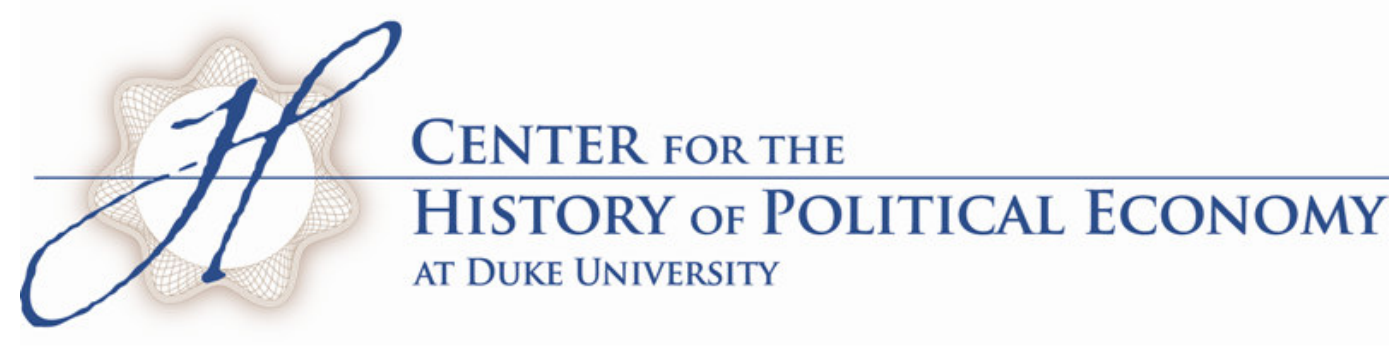


Revised, January 2011

\section{The Monetary Economy and the Economic Crisis*}

by

\section{David Laidler}

Professor emeritus of economics, University of Western Ontario, London, Canada

Fellow in Residence at the C.D. Howe Institute, Toronto, Canada 


\title{
Abstract of \\ The Monetary Economy and the Economic Crisis*
}

by

\author{
David Laidler
}

The monetary economy has properties that cannot be analyzed using the tools of today's dynamic general equilibrium analysis. Keynes's economics, far from being an aberration in the otherwise orderly evolution of modern macroeconomics from Adam Smith's ideas about the "invisible hand", was a major contribution to an ongoing tradition in monetary theory in whose creation Smith himself had played a part. Retrospective consideration of this tradition suggests that the property of the monetary economy critical to the generation of economic crises and the stagnation that follows them is its capacity to permit trading at "false" prices, a phenomenon ruled out by assumption in dynamic general equilibrium models. Not only Keynes's explanation of depression but also Hayek and Robertson's analysis of the role of unsustainable forced saving in the boom can be thought of as relying on this factor.

Key Words: crises, money, monetary economy, general equilibrium, cycles, sticky prices, flexible prices, false prices, rate of interest, forced saving, Keynesian economics, Monetarism, New Keynesian economics,

JEL Classifications: B12, B22, E12, E13, E32, E40.

* Revised version of a lecture presented on August $19^{\text {th }}, 2010$ at a conference marking the opening of the Centre for Economics and Finance in the Faculty of Management and Economics at the University of Santiago de Chile. I am grateful to the Faculty's Dean, Professor Silvia Ferrada Vergara and the Centre's Director, Professor Jose Noguera Santaella for their wonderful hospitality at this event, and to Professor Noguera for his helpful comments on an earlier version of this paper, which also benefited from the efforts of Ms, Carolina Vargas who prepared a power-point summary to accompany its presentation. Much useful criticism of earlier drafts was also provided by David Andolfatto, Roger Backhouse, Daniel Besomi, Tyler Goodspeed, Peter Howitt, Michael Lawlor, Denis O'Brien and Warren Young. Nevertheless, the views expressed here are entirely my own responsibility. 


\section{Stability and Instability in the Market Economy}

A revival of the age-old debate about the inherent stability or otherwise of a decentralized economic system based on private property and voluntary exchange - a market economy as it is usually called - has been one of the very few positive consequences of the economic crisis that began in the summer of 2007.

For the preceding three decades, the prevailing tendency among mainstream economists, particularly in North America and even more particularly among those concerned with analyzing monetary policy issues, had been to take the capacity of such an economy to maintain continuous co-ordination of the maximizing choices of agents at all times as an axiomatic starting point for theorizing, rather than as a matter worthy of investigation in its own right. This was a logically necessary implication of elevating equilibrium modeling methods deriving from the essentially Walrasian microeconomics of Arrow and Debreu to the status of the best, perhaps indeed the only acceptable, professional practice. ${ }^{1}$ While the "Great Moderation" in much of the world economy persisted, the fact, noted by Lucas (2004), that this approach, even in its most recent dynamic stochastic general equilibrium variation, could be of no help in understanding the episodes of instability that had so often arisen in earlier times and/or in far-off places, did not seem to matter very much. The study and explanation of such events was left to economic historians such as, for example, Charles Kindleberger $\left(1978,5^{\text {th }}\right.$ ed. 2005) whose work retained a marginal foothold in some versions of the standard graduate syllabus, and perhaps also to historians of macroeconomic thought - for example Don Patinkin (1982) - or outright heretics for example Hyman Minsky (1982) - whose work by and large did not.

Economic instability has now struck much too close to home for all this to be acceptable any longer, and in this lecture, I shall explore some of the things that the historical literature dealing with the monetary economy once did and might still have to say about these and similar events. I shall do so, not with the intention of instructing my fellow historians, for they know all about these matters already, but in the hope that practitioners of today's monetary economics will take some notice.

\section{This Paper's Themes}

This paper's themes are easily summarized. First, a monetary economy has long been understood by those who have studied it to have properties that cannot be analyzed using the tools of ArrowDebreu style equilibrium modeling, and Keynes's economics, far from being an aberration in an otherwise orderly progress from Adam Smith to today's macroeconomic orthodoxy, was part of a long tradition to which Smith himself had contributed and which studies these properties; second, a critical feature of a monetary economy is its proclivity to permit trading to take place at

\footnotetext{
${ }^{1}$ Robert E. Lucas Jr. (2004) discusses the rise of these methods, which are the basis of work commonly labeled "New-Keynesian" as well as "New-Classical". Beyond doubt, they have produced much interesting analysis, some of which has been of practical policy significance as well. Consider, for example, Michael Woodford (2003). But as I have argued at some length in an earlier paper (Laidler 2010), they have also been intellectually limiting. However, I did not intend then, or now, to issue any blanket indictment of modern monetary theory. Non-Walrasian approaches to the analysis of the monetary economy that build on the pioneering work of Kiyotaki and Wright.(1989) and Kocherlakota (1998) among others have not yet, to the best of my knowledge, developed to the point having any influence on the analysis of real world market economies, let alone monetary policy, but perhaps they will eventually provide a micro-theoretic basis for rigorous discussion of some of the older ideas about the properties of the monetary economy canvassed in this paper.
} 
prices that do not keep markets cleared, false prices as they are usually termed; and third, an understanding of economic crises such as we have recently experienced should be sought in this proclivity, which encompasses not only the economics of depression found in the General Theory, and interpreted by later commentators such as Don Patinkin (1957) Robert Clower (1965) and Axel Leijonhufvud (1968), but also that of the boom as a process of "forced saving" developed by economists such as the so-called "Austrians" Friedrich von Hayek (1933) and Lionel Robbins (1934), but also by Keynes's sometime student, collaborator and, eventual critic, Dennis Robertson $(1926,1928)$ among others.

\section{Misconceptions about the History of Macroeconomics}

The last two years have already seen a lively debate about the desirability of giving up today's dominant approach to macroeconomics and returning to what might be called old-Keynesian economics. $^{2}$ This debate has been profoundly unsatisfactory. Though its protagonists have found much to disagree about concerning the relative merits of old-Keynesian and modern economics, they have nevertheless shared a common but misconceived view of the places of these competing doctrines in the development of economic thought.

\section{Keynes's Place in the Story}

At the risk of over-simplifying for the sake of brevity, this common view can be summarized as follows. First, modern dynamic stochastic general equilibrium analysis is the outcome of the orderly and systematic elaboration over almost two and a half centuries of Adam Smith's ideas, as set out in The Wealth of Nations, about how the pursuit of individual self-interest in competitive markets leads, as if by the workings of an "invisible hand", to a coherent outcome at the level of the economy as a whole in which individual strategies are fully coordinated. Second, John Maynard Keynes's (1936) General Theory of Employment Interest and Money, inspired by the economic turbulence of the inter- war years, presented a radically alternative point of view, that for a while, but only a while, became the basis of a new economic orthodoxy that was skeptical about the inherent stability of a largely unregulated economy and hence provided justification for more or less continuous activist policies designed to keep it on track.

Robert E. Lucas Jr. (e.g. 1996, 2004, 2009), Paul Krugman (e.g. 2009), George Akerlof and Robert Schiller (e.g.2009), to name a few of the most distinguished contributors to recent debates have all assented to versions of this account of the history of macroeconomic thought and Keynes's place in it. What they have disagreed about is its significance. For Lucas, the first rise of old-Keynesian economics amounted to a temporary triumph of politics over economic theory and its fall from grace represented a return of the discipline to a previously dominant and scientifically progressive path on which it now ought to remain. For the others, those same developments represented an attempt to revolutionize the subject for the better that regrettably failed, but which, in the light of recent events, might turn out to have suffered more of a temporary set-back than a decisive defeat.

In earlier work, for example Laidler (1999), I have argued that this view of Keynes's place in the development of macroeconomics is thoroughly misconceived, and in a more recent paper (Laidler 2010) I have taken up a complaint voiced long ago by Frank Hahn (1965) and suggested that the fundamental problem with modern equilibrium macroeconomic modeling

\footnotetext{
${ }^{2}$ I use this designation in order to distinguish what might otherwise have been called just "Keynesian" economics from the so-called "New-Keynesian" version of dynamic stochastic general equilibrium modeling, with which it has almost nothing in common.
} 
from the outset has been that it leaves no room for phenomena stemming from the fact of monetary exchange to be analyzed. From this it follows that the inability of this approach to deal with financial crises, noted by Lucas (2004) is therefore inherent in its very structure, and that a "business as usual" approach to its further development is unlikely to produce satisfactory results. I have also re-iterated my (1999) view that, overblown though Keynes's own claims about the revolutionary nature of his work might have been, his demonstration of how the distinctive nature of an economy based on monetary exchange can lead to lapses from fullemployment makes the General Theory a work of lasting scientific importance. But I have nevertheless resisted the temptation to join today's old-Keynesians in claiming oracular status for that work in the context of today's troubles.

\section{Limitations of old-Keynesian Economics}

Original though the General Theory's specific analysis of the emergence of unemployment in a monetary economy is, this phenomenon is only one among several associated with the recent economic crisis - not to mention its many predecessors - that needs explaining. Furthermore, analysis of the distinctive properties of the monetary economy already had two centuries of history behind it before Keynes himself took it up, and that history continued vigorously into the 1970s before the rise of a macroeconomics grounded in the Arrow-Debreu general equilibrium approach came close to cutting it off. Such analysis had many helpful things to say about economic crises that are not to be found in the General Theory, so instead of returning to a specifically "old-Keynesian" economics in response to the events of the last three years, it might be more useful to revive the broader tradition of monetary analysis to which that economics was but one, albeit important contribution. This tradition has very little to do with modern myths about how today's equilibrium macroeconomics evolved from Adam Smith's ruminations about the workings of the "invisible hand" by way of Walras and Arrow-Debreu.

\section{The Monetary Economy}

As the commonly used phrase has it, ours is a market economy, whose most fundamental characteristic is the generation and distribution of wealth, not just by the production of goods and services, but crucially by their voluntary exchange. Just as fundamental is the fact that the voluntary exchange in question is usually indirect and mediated through a monetary and financial system. ${ }^{3}$

\section{Today's Monetary System}

To resort to a homely example, in today's economy, auto-workers do not barter hours of work for SUVs and hybrids, which they simultaneously swap for food and clothing at the mall and offer as mortgage payments or retirement account contributions to the bank, insurance company or other institution. Though this scenario does, on a fundamental level, characterize the ultimate nature of the exchanges that take place in a market economy, the transactions by which these are realized are very different. Auto-workers are paid wages in money, which their employers obtain by selling cars (or by borrowing in anticipation of such sales), and at the mall they buy goods and services with that money (or perhaps on credit which they will later pay off by a transfer of

\footnotetext{
${ }^{3}$ As David Andolfatto has reminded me, this is also the starting point for modern search theoretic approaches to the analysis of money, which is why (fn. 1) above, without embracing it, I explicitly exempt this work from my criticism of modern macro-theory. The reader should also note that an earlier draft of the next few paragraphs first appeared in Laidler (2006)
} 
money to the lender), and they make money payments to meet interest obligations on their mortgage debt and to reduce its principle, and perhaps to increase their retirement account balances as well.

The monetary system's most primitive task, still much discussed in the textbooks, is thus to provide a common means of exchange which also serves as a unit of account in which prices are stated, so that goods and services may be traded in spot markets. In today's economy, however, such trading is intertwined with transactions involving the passage of time. The transfer of deposit liabilities of financial institutions that typically consummates spot transactions - government issued currency is merely small change, and privately issued currency a rarity and the once sharp distinctions among immediately chequable accounts and those meant to hold savings have long since been eroded. There is, therefore, no clear-cut line between those instruments used as means of exchange in current transactions and those representing financial claims on the future. Moreover, though agents who save are, on some abstract level, trading with themselves over time, exchanging current against future consumption; the transactions through which this trade is realized typically involve the transfer by them of money that could have been used to buy consumption goods in the present to some other agent in exchange for a claim on money at some time in the future. Current and planned future transactions are thus inextricably linked when saving decisions are executed, as they are on the other side of the same transactions as investors use borrowed money in the present to buy resources that are to be used to produce goods for sale in the future.

Agents who are continuously engaged in monetary exchange find it convenient to hold inventories of the means whereby the relevant transactions are mediated. Even transactions whose timing is regular and predictable require them to have money on hand when they occur; this is the basis of what the textbooks call the "transactions" demand for money. Because the timing and even scale of much market activity is uncertain, however, agents also hold "precautionary" balances. Furthermore, whatever serves as money must be rather durable, so it can also be held as a store of value pure and simple, and in this latter role it becomes a substitute for other liabilities emitted by the financial system that do not themselves serve as a means of payment in spot markets, but which can be exchanged for money, more or less easily, depending upon the nature of the asset itself, and/or upon the depth and efficiency of the markets in which they can be traded. This "asset" demand for money varies with the rates of return available on those other assets, and individual agents' decisions about how they manage their inventories of money are thus, as Keynes $(1930,1936)$ stressed, inter-dependent with their plans for the allocation of consumption and production over time. ${ }^{4}$

Enabling agents to cope with the passage of time and uncertainty about the future are central functions of the monetary system. Different agents have different attitudes towards risk, different capacities for assessing it, for valuing it, and so on, and because it is the monetary system that co-ordinates those agents' activities, it is also through its workings that they seek to overcome what Keynes called "the dark forces of time and ignorance" in whatever ways they deem best for themselves. Today's monetary system provides myriad possibilities, direct and indirect, for linking consumers with producers, savers with investors, and for coordinating their plans, and it is continuously evolving new means of dealing with these matters.

It is well understood that, if a market economy is to work as if guided by an "invisible

\footnotetext{
${ }^{4}$ I deliberately refrain from using Keynes's label "speculative demand" here, because it refers to a particular way of analyzing the demand for money as an asset - a store of value - rather than to the general phenomenon of what Keynes called "liquidity preference".
} 
hand" to ensure that the actions of self-interested individuals lead to coordinated and desirable social outcomes, the information and incentives embedded in the prices facing those individuals must reflect the real social costs and benefits of their actions. That information and those incentives, however, are transmitted through the monetary system, and their communication through prices stated in terms of money has often and aptly been compared to the communication of ideas by way of a common language. Just as ambiguity, not to mention deliberate deception, in the use of language are always potential sources of trouble, so too are misleading messages about the present and unreliable promises about the future, delivered by money prices.

\section{The Monetary Fingers of Smith's Invisible Hand}

Now there is nothing that a well trained economics undergraduate would find startling or new in the last few paragraphs, but it is worth pointing out explicitly that none of the phenomena which they describe have explicitly featured - at least until very recently - in those modern dynamic general equilibrium models of the economy in terms of which monetary policy issues have been analyzed. Those models begin with the assumption that agents will always be able to complete their planned transactions because the prices they face are always kept at a market clearing level "as if" by the operations of an entity to whom Lucas (2004) has referred to as a "very fast auctioneer", and they also evade the awkward issues raised by Keynes's above-mentioned "dark forces" by attributing "rational" expectations to those same agents, views of the future based on a correct understanding of the economy's structure as well as their place in it, and informed by accurate and (up to a certain level) complete information of the nature of the shocks that might impinge upon it.

As I have remarked elsewhere (e.g. Laidler 2010), the "as if" auctioneer-supervised "market" whose mechanisms co-ordinate these model economies is thus a metaphor for the actual economy's monetary system and, because its mechanisms are presumed always to work, these models can neither help us understand why real world monetary systems sometimes break down, or what might then happen as a consequence. Or to return to, and extend, Smith's much more famous metaphor, the invisible hand that guides the market economy has monetary fingers, and when these fail to function properly, so does the market economy.

Adam Smith himself knew full well that the mechanisms of voluntary exchange over which the "invisible hand" presided depended on a monetary system. ${ }^{5}$ The famous chapter 3 of Book 1 of the Wealth of Nations (Smith 1776), "That the Division of Labour is Limited by the Extent of the Market" is immediately followed by Chapter 4, "Of the Origin and Use of Money", one of whose themes he summarized as follows ". . money has become in all civilized nations the universal instrument of commerce, by the intervention of which goods of all kinds are bought and sold, or exchanged for one another" (p.44). The similarity between Smith's message here and that set out above about the role of money is entirely un-coincidental, and he had much else to say that is of direct relevance to this lecture. In particular, and more enthusiastically than his friend David Hume, Smith was a supporter of his native Scotland's then recently developed system of commercial banking with its overdraft system for financing business, and in particular of the replacement of gold and silver coin by the paper money that the country's note-issuing banks emitted. But though enthusiastic about these institutional innovations, he was not uncritical:

"The gold and silver money which circulates in any country may very properly be

\footnotetext{
${ }^{5}$ I have discussed all this in some detail in "Adam Smith as a Monetary Economist" (Laidler 2004, Ch. 1)
} 
compared to a highway, which, while it circulates and carries to market all the grass and corn of the country, produces itself not a single pile of either. The judicious operations of banking, by providing, if I may be allowed so violent a metaphor, a sort of waggonway through the air; enable the country to convert, as it were, a great part of its highways into good pastures and corn fields, and thereby to increase very considerably the annual produce of its land and labour. The commerce and industry of the country, however, it must be acknowledged, though they may be somewhat augmented, cannot be altogether so secure, when they are thus, as it were, suspended upon the Daedalian wings of paper money, as when they travel about upon the solid ground of gold and silver. Over and above the accidents to which they are exposed from the unskilfulness of the conductors of this paper money, they are liable to several others, from which no prudence or skill of those conductors can guard them" (p. 321)

Or to put it more succinctly: it was Adam Smith's carefully considered view that monetary exchange is essential to the workings of a market economy and that to base it on paper money issued by banks in the course of granting credit to the business community, though extremely productive, is risky, not only because bankers sometimes make mistakes, but also because the banking system is subject to shocks originating elsewhere whose impact they can do nothing to avoid. Not surprisingly, in the light of these views, banking was one of those areas of economic activity that Smith thought might benefit from a little state regulation, which he defended in the following terms. ${ }^{6}$

"Such regulations may, no doubt, be considered as in some respects a violation of natural liberty. But these exertions of the natural liberty of a few individuals, which might endanger the security of the whole society, are, and ought to be, restrained by the laws of all governments; of the most free as well as the most despotical. The obligation of building party walls, in order to prevent the communication of fire, is a violation of natural liberty, exactly of the same kind with the regulations of the banking trade which are here proposed." (p.324)

The fears of the contagion inherent in financial instability that are so apparent in this passage surely reflect the fact that Smith knew something of what had happened earlier in the eighteenth century with the Mississippi and South Sea bubbles, and closer to home, a great deal about the economic disruptions in Scotland associated with the collapse of the Ayr Bank in 1772.

Smith's overall intellectual authority as an economist ensured that his successors would take notice of his views on the essential role played by the monetary system in the market economy, on that system's inherent fragility, not to mention on the possibility of strengthening it by suitable designed government intervention. These basic themes have been central to monetary economics since the $18^{\text {th }}$ century, though of course the subsequent variations worked on them by Smith's successors were anything but homogeneous and often differed widely from his. Even so, there is at least as much in the Wealth of Nations to link Smith to old- Keynesian economics as there is to link him to Arrow and Debreu and thence to modern equilibrium modeling, and today's prevailing views of what the subsequent development of economic analysis owed to him are misleadingly simplistic.

\footnotetext{
${ }^{6}$ Specifically, he advocated (1776, pp.322-329) that convertibility of their paper liabilities on demand into specie be legally required of bankers, and that their note issue be limited to denominations high enough to ensure that they circulated only among members of a financially sophisticated business community.
} 


\section{Selected Lessons from the Subsequent History of Monetary Economics}

This is not the place for a systematic account of the evolution of Classical monetary economics after 1776. Suffice it to note that the British financial crises associated with the outbreak of the French Wars in 1793 and an invasion scare in 1797 gave a major boost to the subject's development, not least as exemplified by Henry Thornton's extraordinarily penetrating Enquiry into the Nature and Effects of the Paper Credit of Great Britain (1802) whose title not only (surely self-consciously) echoed that of Smith's great book, but whose text also contained a lengthy critique of its treatment of monetary matters, and that as the nineteenth century proceeded, it became successively evident, first that such crises recurred rather regularly, and, a little later, that they were in fact but one, albeit conspicuous, feature of a repeating sequence of events that, in the twentieth century, eventually came to be called "the business cycle". ${ }^{7}$

\section{The Overstone Cycle of Trade}

As early as 1837 the banker and politician Samuel Jones-Loyd, later Lord Overstone, pointed out that "the state of trade revolves apparently in an established cycle. First we find it in a state of quiescence - next, improvement- growing confidence - prosperity - excitement - overtrading convulsion - pressure - stagnation - distress - ending again in quiescence", and at some time in the late 1850s, his characterization of economic activity as following an ever repeating pattern (with slightly modified and simplified semantics) was sufficiently widely known and accepted to be the subject of the anonymous cartoon displayed here as Figure $1 .{ }^{8}$ This remarkable composition gives a concise visual account of what we would nowadays call the "stylized facts" of the cycle as they were understood a century and a half ago, and it still has considerable resonance for today's situation, not least in making it quite clear that market economies have been here many times before.

But it has more specific messages for us too. Those regarding the manner in which orderly behaviour of a type with which today's mainstream macroeconomists might perhaps be comfortable - "improvement" "confidence" and "prosperity" - evolves into "excitement", "convulsion:", and "stagnation" are particularly pertinent. Note, for example, that "excitement" whose modern synonym is surely "exuberance" - is depicted here not primarily as a feature of financial markets, but of the real economy. The monetary system is present in the picture, to be sure, represented by "scrip," stocks" and "shares", and a bank that seems to be offering loans at 2 percent, but at its centre are eager crowds, presumably of would-be investors, gathered outside the offices of the "South Pole Warming Company" over which an exotic flying machine seems to be hovering. It is only when the foolishness of these undertakings has been revealed - how, we are not told - and "convulsion" - "panic" in today's vocabulary - has set in, that the monetary system comes to dominate the scene as the premises of the "Royal Bubble Bank" explode. It is surely not far fetched to see parallels in these two panels with the enthusiasms of a few years ago.

\footnotetext{
${ }^{7}$ I have discussed the evolution of these ideas in "Rules, discretion and financial crises in classical and neoclassical monetary economics" (Laidler 2004, Ch.2)

${ }^{8}$ The cartoon is already well known historians of monetary economics. It appears in Denis O'Brien's edition of Overstone's Correspondence (O'Brien, ed. 1971), and I am indebted to O'Brien and to Daniel Besomi for correspondence about it and related matters. Besomi (2011) shows that this cartoon first appeared in an anonymous (1858) article attacking the 1844 Bank Charter Act, of which Overstone had been a major architect..
} 


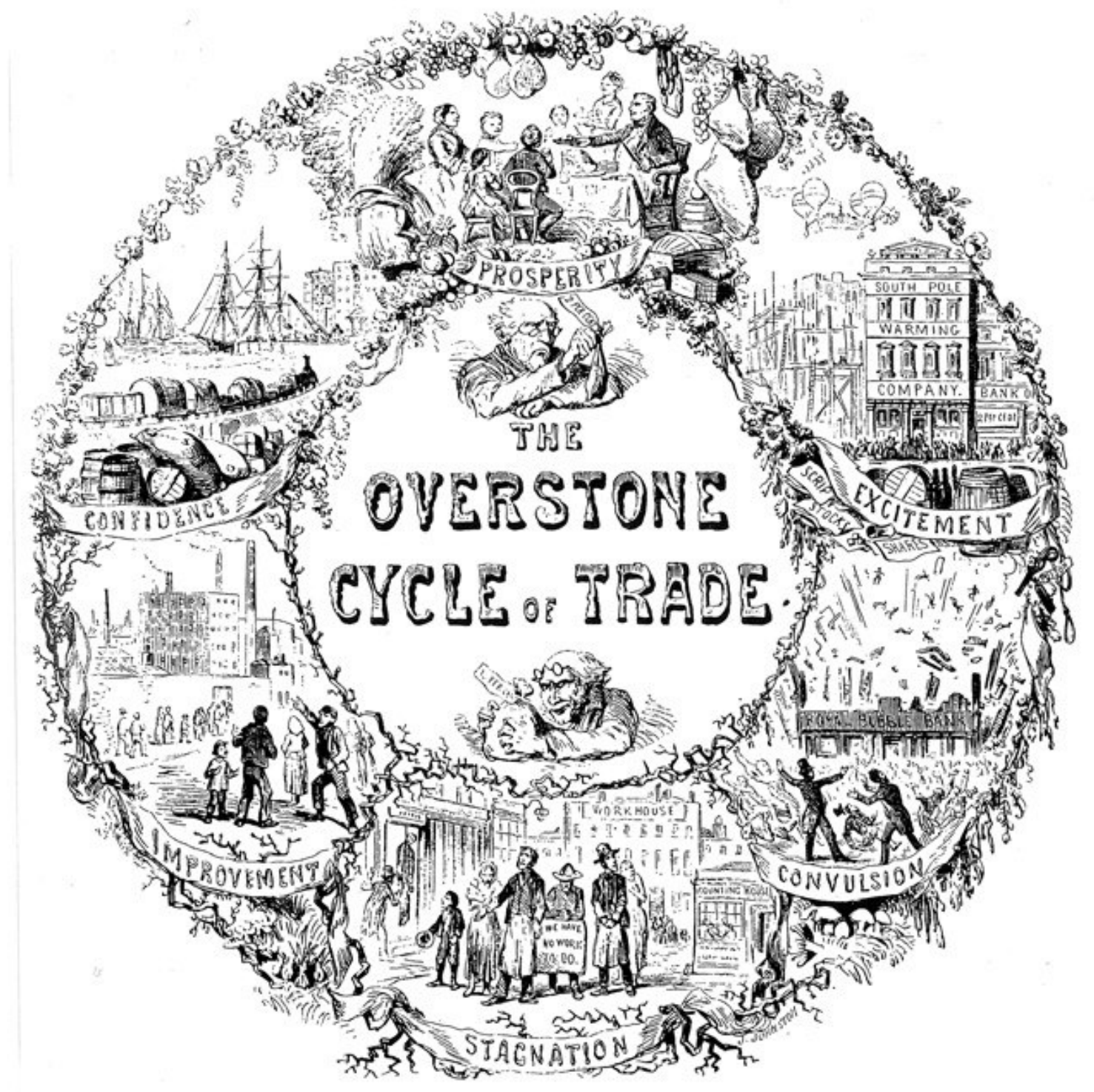

Trade Cycle cartoon, from a print 
in the US and certain European countries - notably Ireland and Spain - for ambitious housing construction projects and related activities that were exotically financed at low interest rates, or with the collapses in the financial sector - for example the explosion of Lehman Brothers - that followed the onset of a quickly spreading realization, well informed by hindsight, that all too many of these had been foolishly over-ambitious.

If we bring the economic understanding of the late 1850s, as displayed in this cartoon, to bear on the market economy's most recent crisis, we should take particular note of its suggestion that economic instability is not exclusively a phenomenon of the monetary system, and conclude that the label "financial" that is often attached to it nowadays is misleadingly narrow. This old cartoon in fact confirms a critical implication of the view expressed above; namely, that because in the real world the monetary system performs the tasks that modern equilibrium models assign to the "market", the disruption of that system is also a disruption of the real economy. And the cartoon's depiction of the "stagnation" that follows "convulsion" re-enforces this message further. The sign carried by those unfortunates standing in the shadow of the workhouse does not read, as it would in a dynamic stochastic general equilibrium model in which the labour market always clears - even if subjected to rigidities associated with Calvo contracts - "we are consuming extra leisure while the opportunity cost of doing so is unusually low", but simply, as is appropriate to the real world of a disrupted monetary economy, "we have no work to do"9

\section{Say's Law, Money and Sticky Prices}

To put the same point less obliquely, today's dynamic general equilibrium models can generate variations in the levels of real activity and employment, but by their very nature they must treat these as reflecting voluntary behaviour in markets for goods and services that are continuously clearing. In this respect they embody an up-to-date and extreme version of what at one time was commonly referred to as "Say's law", the proposition that a general glut - excess supply in modern terminology - of goods and services is impossible. ${ }^{10}$ Keynes, of course, argued that "Classical economics", citing John Stuart Mill among others as its representative, relied on this proposition, and claimed his refutation of it in the case of a monetary, as opposed to a barter economy, to be a critical innovation of his General Theory, thus helping to originate today's misleading but standard view about the essential continuity of modern equilibrium modeling with the economics of Adam Smith and his Classical successors.

Some of what Mill himself actually wrote about this matter as early as 1828 - though he did not publish it until the appearance of Mill (1844) - is therefore worth quoting. "There can never, it is said, be a want of buyers for all commodities; because whoever offers a commodity for sale, desires to obtain a commodity in exchange for it, and is therefore a buyer by the mere fact of being a seller. The sellers and the buyers, for all commodities taken together, must, by the metaphysical necessity of the case, be in exact equi-poise to each other; and if there be more sellers than buyers of one thing, there must be more buyers than sellers for another.

This argument is evidently founded on the supposition of a state of barter, and on that supposition, is perfectly incontestable. .. . If, however, we suppose that money is used,

\footnotetext{
9 The unemployed are, nevertheless, not the most unfortunate agents in the panel - look in the doorway on its left

10 "Extreme" because 19th century versions of Say's law permitted the existence of excess demands for some goods and services being offset by excess supplies of others. When markets continuously clear, even this possibility is ruled out.
} 
these propositions cease to be exactly true .... Interchange by means of money is, as it has often been observed, ultimately nothing but barter. But there is this difference that in the case of barter, the selling and the buying are yet simultaneously confounded in one operation ... the effect of the employment of money, and even the utility of it, is, that it enables this one act of interchange to be divided into two separate acts or operations. ... .when there is a general anxiety to sell, and a general disinclination to buy, commodities of all kinds remain for a long time unsold, and those which find an immediate market, do so at a very low price.. . . But those who have, at periods such as we have described, affirmed that there was an excess of all commodities, never pretended that money was one of those commodities; they held that there was not an excess but a deficiency of the circulating medium. What they called a general super-abundance, was not a super-abundance of commodities relative to commodities, but a superabundance of all commodities relatively to money" (Mill 1844, pp. 69-71

Now "a general anxiety to sell" is a central characteristic of what our anonymous cartoonist called "convulsion", and Mill was here exploring the economy's transition from this state to one of "stagnation". But he did not complete this task, either in (1844) or in the parallel passages dealing with the cycle in his (1848) Principles. In (1879), however, Alfred and Mary Paley Marshall paraphrased Mill's by then quite standard account, noted that "the connexion (sic!) between a fall of prices and a suspension of industry remains to be worked out" (Marshall and Marshall 1879, p. 155), and proceeded to fill in this gap by examining the consequences of the fact that "... when prices are falling, the fall in the price of a finished commodity is generally more rapid than that in the price of the raw material, always more rapid than that in the price of labour" (p. 156, italics added). Thereafter, and for more than half a century before the publication of the General Theory, nominal wage stickiness was the standard "Classical" explanation of unemployment in a monetary economy, and today's practice of making it the defining postulate of "New-Keynesian" macroeconomics is simply another symptom of how badly our discipline's history is misunderstood by its practitioners. ${ }^{11}$

\section{Keynes on the Irrelevance of Price Stickiness}

Keynes himself explicitly argued that money wage stickiness, though a useful simplifying assumption for expounding his own theory of how Say's law might fail was in no way essential to it. Though his claim to have moved beyond his predecessors simply by dissenting from that law is not credible, his attribution of its failure in a monetary economy the fact that the rate of interest's role in equilibrating the supply and demand for money interfered with its ability to

\footnotetext{
${ }^{11}$ I discussed the evolution of ideas about wage and price stickiness in my 1991 Henry Thornton Lecture "Wage and price stickiness in macroeconomics: an historical perspective" (Laidler 2004, Ch.12) Wage stickiness had made a brief appearance in Henry Thornton's (1802) Paper Credit but only found a central place in the mainstream literature after the Marshalls' deployment of it. Their analysis, and that of their immediate successors, not least Pigou (e.g.1913), went on to emphasize the effects on real wages and hence on the demand for labour of interactions between sticky wages and more flexible prices, thus deploying a not quite satisfactory application of partial equilibrium labour market analysis to the economy as a whole to explain the emergence of unemployment. In (1913), however, Ralph Hawtrey began to argue that the real significance of wage stickiness arose because, by way of mark-up mechanisms, it created stickiness in money prices too, thus inhibiting the price level adjustments needed to eliminate the excess demand for money and associated excess supplies of output and labour that developed during the transition from "convulsion" to "stagnation".
} 
maintain equilibrium between saving and investment when the latter declined suddenly as the "animal spirits" of businessmen collapsed, was both novel and important. So was his explanation of "stagnation" characterized by low output and employment as the outcome of an alternative equilibrating mechanism that operated through the celebrated multiplier process. ${ }^{12}$

Keynes did, to be sure, concede that the forces leading to and sustaining stagnation could in principle be counteracted by lower levels of money wages and hence prices, but he was extremely skeptical about the practical significance of these mechanisms. To begin with, the route whereby they had to work was indirect. It ran through money wage adjustments in labour markets to price adjustments in output markets, and thence to the supply and demand for money, in order finally to relieve pressures in another market altogether, that in which savings and investment decisions were linked by the interest rate. Second, and more important, though downward wage and price flexibility was required for these indirect mechanisms to work at all, the fact of falling wages and prices was likely to have effects on the dynamics of the adjustment process, particularly by way of extrapolative deflationary expectations, that might make the attainment of equilibrium impossible. Hence Keynes's conclusion that wage flexibility could and should not be counted on either to prevent real stagnation emerging in a monetary economy, or of relieving it once it had .become established. Provided it is understood that by such flexibility, Keynes meant wages and therefore prices which move quickly when markets are out of equilibrium, and not wages and prices that always move quickly enough to keep them in equilibrium in the first place, his argument about its essential irrelevance must be taken seriously, not as a general proposition about how a monetary economy always functions, but as a warning about the risks of malfunction to which it is vulnerable when trading can take place at out-of-equilibrium prices, flexible or not. ${ }^{13}$

It was the later work of such as Patinkin (1957) Clower (1965) and Leijonhufvud (1968) on the links between old-Keynesian and Walrasian economics that brought into monetary economics two already established ideas from microeconomic theory. First, that when the market economy's equilibrium is disturbed by a shock of some sort, a return to equilibrium can only be guaranteed if no production or trading are undertaken before prices have attained their new array of market clearing values, that there is no trading at "false" prices; and second, that such an outcome requires the economy to operate "as if" an agent specially appointed to oversee the price formation process - a so-called Walrasian auctioneer - prevents any such trading or, equivalently, works so fast to change prices that they never deviate from their market clearing values in the first place.

\section{Walras on the Empirical Relevance of General Equilibrium}

This famous entity did not figure in any of Leon Walras' own accounts of these matters. ${ }^{14}$ Rather

12 Though Keynes did not pay much attention to the cycle as such in the General Theory, it does no violence to his analysis if we attribute to him the belief that the economy's transition from "excitement" through "panic" to "stagnation" was largely driven by a collapse of animal spirits rather than by the monetary contraction which Marshall, Fisher, Hawtrey et. al. emphasized,

${ }^{13}$ The importance of distinguishing between these two senses of "flexibility", and the relatively recent appearance of the second of them in macroeconomics, is explored at some length in Laidler (2004, Ch. 12). It is because of its reliance on assumptions of wage and price rigidity that I do not at this point pay attention to the formal analysis of the properties of non-clearing markets, surveyed, for example by Benassy (1993)

${ }^{14}$ On Walras' treatment of these matters, see in particular, Patinkin (1957), Note B, "Walras' Theory of 
he envisaged equilibrium prices being discovered by way of a tatonnement process that involved a price in terms a common unit of account - the system's so called numeraire - being cried out for

". . . each type of land and labour service, and product.. If at that price the quantity effectively demanded exceeds the quantity effectively supplied, entrepreneurs will bid that price up. If the quantity effectively supplied exceeds the quantity effectively demanded, landlords, workers and capitalists will reduce their asking prices. The ruling price is the one at which effective demand and supply are equal." (Walras, 1886, p. 26, my translation)

And in Walras' own accounts of how markets work, goods and services are exchanged, not "as if" by multilateral barter, but by exactly the same system of bilateral monetary exchanges as envisaged by Adam Smith and Mill, in which the item serving as the system's numeraire is also its means of exchange. Walras was aware that trading at false prices could cause problems (more so when he dealt with a production than a pure exchange economy however) though his efforts to deal with these were not quite satisfactory, even from a purely theoretical standpoint. More important, however, from the point of view of the history of monetary economics, Walras himself never claimed that the equilibrium characteristics of his theoretical system should be interpreted as mimicking the observable behaviour of any real world economy in the way that today's exponents of dynamic general equilibrium modeling do. ${ }^{15}$ On the contrary, ". . the market is like a lake agitated by the wind, where the water is incessantly seeking its level without ever reaching it. But whereas there are days where the surface of the lake is almost smooth, there never are days when effective demand for products and services equals there effective supply and when the selling price of products equals the cost of the productive services used in making them. The diversion of productive services from the enterprises that are losing money to profitable enterprises takes place in various ways, the most important being through credit operations, but at best these ways are slow. It can happen and frequently does happen in the real world, that under some circumstances the selling price will remain for long periods of time above the cost of production and continue to rise in spite of increase in output, while under other circumstances a fall in price, following upon this rise, will suddenly bring the selling price below cost of production and force the entrepreneurs to reverse their production policies. For just as a lake is, at times, stirred to its very depths by a storm, so also the market is sometimes thrown into violent confusion by crises, which are sudden and general disturbances of equilibrium." (Walras, 1874-81, tr. 1956, p. 380))

As we noted earlier, macroeconomic models based on the postulate of continuously clearing markets cannot address the kind of instability envisaged here by Walras, which seems to have long been, and remains, a rather regular feature of economic life in modern market economies. And we have now seen that these difficulties stem from a fact that was understood with ever increasing clarity from the very beginnings of economics until about thirty years ago, when its significance began to be neglected, namely that what we call market economies are

Tatonnement" and Note C "Walras' Theory of Money". It should also be noted that Joseph Ascheim and George Tavlas (e.g. 1991) have stressed the importance of money's unit of account role in the price setting process in the development of Classical monetary doctrines.

${ }^{15}$ It is worth noting that the following analogy with the surface of a lake, taken from the Elements, is also deployed in Walras' Theorie de la Monnaie. Such repetition suggests that he thought the point he was making to be important. 
really monetary economies, and differ in essential ways from systems which function "as if" presided over by an auctioneer. And specifically, as we also learned along the way, it is not that the monetary economy is subject to wage and/or price stickiness that matters, even though it might be, but that its workings permit decisions about quantities to be made and implemented in response to "false" wages and prices and that these decisions can sometimes have destabilizing consequences. $^{16}$

\section{Explaining Stability and Instability}

This conclusion can all too easily explain too much. If trading at false prices can create unstable quantity dynamics, and if it is likely to occur in a monetary economy, then why are such systems not in a perpetual state of disarray? How can we explain episodes such as the "Great Moderation"? The answer here perhaps lies in another feature of the monetary economy, namely that its operations give rise to demand for inventories of the economy's means of exchange, and close substitutes for them, on the part of individual agents, an idea first explicitly developed by two economists who have already played a prominent role in the foregoing discussion, namely Marshall and Walras.

\section{Monetary Buffers and the Corridor of Stability}

Marshall, in an unpublished manuscript of 1871 or thereabouts, put matters as follows:

"If any man keeps accounts accurately by subtracting his payments up to any day from

his receipts up to that day we know the cash he has on hand at the beginning of that day. Add up these sums for each day, divide by the number of days, and we have the amount of cash he has each day on average" (Marshall 1871, [1975], Vol. 1, p. 175),

And it is this average amount about whose determination he then proceeded to theorize, a quantity that that we have long since learned to call the individual agent's "demand for money".

A key point here is that the agent's actual holdings of money on any of Marshall's days can differ from that same agent's demand for money because those holdings serve as a "buffer stock" that stands between irregularities in the pattern of payments and receipts, and they derive their usefulness from insulating plans that have been made about one of these from unexpected fluctuations in the other. ${ }^{17}$ This is where the "convenience" of holding money comes from, and it explains both why the target value that agents set for their average balances varies in proportion to the average price level at which transactions are to be executed - a point of which Marshall made much, as did Walras in his own later (1886) but independent account of these issues - and also moves up and down with some measure of the real scale on which those transactions are carried out.

Money's buffer-stock role has potentially important consequences for the nature of the monetary economy. When an agent encounters a quantity surprise as a result of trying to trade at what turns out to have been a non-market clearing price in one market, provided that shock is not "too large", his inventory of cash balances can absorb it and costly changes in behaviour in other markets are not immediately forced upon him. Agents who hold buffer stocks of money thus face reduced incentives to gather costly information that might help them to reduce their error-

\footnotetext{
${ }^{16}$ Calvo contracts can, after all be introduced into equilibrium systems and their markets continue to clear subject to the constraints they impose. That is what the New-Keynesian variant of dynamic general equilibrium modeling relies on.

${ }^{17}$ I have discussed money's buffer stock role, and its implications elsewhere. See for example, Laidler (1988) where references to my earlier and in some respects fuller treatments of these issues are also given.
} 
proneness, and as a result, their behaviour is likely to reflect expectations based on less than all the information that is available in the market place and on less than a full understanding of the "true model" that characterizes the economy's properties. At the same time, the capacity of fluctuations in monetary buffers to absorb the consequences of trading at false prices gives the aggregates economy a degree of insulation against the dynamic instability that such trading can generate. Furthermore, in a modern economy, the opportunities for agents to provide themselves with monetary buffers go far beyond holding inventories of the means of exchange. Any asset which can be rapidly and reliably converted into cash at low cost can also play this role.

Despite the proclivity of agents in a monetary economy to make errors, and to trade at false prices, then, so long as the shocks that impinge on them are not "too large", the existence monetary buffers will permit the economy to remain in what Leijonhufvud (1973) and Peter Howitt (1978) call a "corridor of stability" and perhaps to behave very much as predicted by a dynamic general equilibrium model. Considerations such as these help reconcile the monetary economy's capacity for generating instability with episodes like the "Great Moderation". But they leave open the possibility that from time to time, shocks that are "too large" might hit "too many" agents and markets at once, and set up dynamics that drive the real economy out of its stable corridor towards "stagnation". Possibilities that come to mind here include sudden falls in the economy-wide supply of money that provoke attempts by a significant number of agents to restore their individual buffer-stocks by selling other assets, and/or altering their planned patterns of buying and selling real goods and services, widespread shocks to confidence - such as Mill postulated in 1828 - that provoke similar behaviour as agents try to increase the size of their monetary buffers, and of course, in today's economy, malfunctions in the markets for some of the non-money assets that had seemed to be reliable buffers in their own right that suddenly reduce their perceived marketability.

All of these conjectures might help explain how a monetary economy can progress from "convulsion" to "stagnation", but they nevertheless start in the middle of the story. Recent events also require us to explain also how the movements from "prosperity" to "excitement" that precipitate "convulsion" develop, and here the history of monetary economics is almost too helpful in the number and variety of possible answers it offers. However, there are certain recurrent facts about the onset of crises that not every theory deals with adequately, and we can use these to narrow down the field.

\section{Monetarist and Old-Keynesian Explanations of the Onset of Crises}

It is well known that upswings during which the transition from "prosperity" to "excitement" occurs are usually marked by a noticeable increase in the rate of price inflation. So-called "Monetarist" explanations of this transition pay particular attention to this fact, and since Alfred Marshall (1887) and Irving Fisher (1911) have explained it in terms of the failure of nominal interest rates to adjust fast enough as inflation gets under way to prevent real interest rates from falling. ${ }^{18}$ This effect in turn puts upward pressure on credit and money growth and therefore, as

\footnotetext{
${ }^{18}$ I adopt the adjective "monetarist" here because the so-called Fisher effect (which was actually discussed by Marshall, before Fisher took it up) is central to the work of Friedman and Schwartz (e.g. 1963) and Allan Meltzer (e.g. 2003) on this topic, but this line of argument has gone through many more variations and elaborations over the years than can be discussed here. There is no consensus this approach's exponents, for example about what kind of shocks might set "improvement" and "confidence" in motion in the first place, with some of them - e.g. Hawtrey (1913) - even treating the cycle as a self-perpetuating phenomenon.
} 
agents respond to a perpetual tendency of money to be in excess supply, on expenditure as well. Inflation then rises further, and so on, in an ongoing spiral. In this story, crises and recessions ensue in due course, either, in its older versions, because the banking system finds its reserves under pressure and belatedly increases nominal interest rates or, in modern versions because monetary slowdowns intended to bring inflation under control are engineered by policy makers..

There is much to be said for this explanation of the development of "excitement" and its subsequent unwinding into "convulsion", and it seems to account well for many episodes of instability since the Second World War - not least those that accompanied the great inflation that preceded the stabilization efforts of that well known composite politician "Ronald Thatcher". But there have been episodes and facts that it does not deal with. First, and most obviously, some striking episodes of "excitement", "convulsion" and subsequent "stagnation" were not preceded by noticeable increases in the rate of price inflation. The United States experienced a stable and even slightly falling price level before the October 1929 stock-market crash that heralded the onset of the Great Depression; Japan's "lost decade" was preceded by only a slow rise in inflation that barely reached a 3 per cent peak in 1992, a year after the stock market bubble had burst; and prior to the summer of 2007, though US inflation did exceed 4 per cent for a while, and with hindsight perhaps ought to have triggered a little concern, the price level's overall behaviour gave no forewarning of the scale of problems that were to follow. Troubling also is the fact that, while the Monetarist story does not explicitly rule out the frequent tendency for "excitement" to be accompanied by over-optimistic investment projects whose collapse leads to insolvencies among lenders as well as mere liquidity problems - that "South Pole Warming Company and Royal Bubble Bank" of our cartoon, or, more recently, all of those now semi-derelict housing developments in Arizona, Florida, Ireland, Spain and elsewhere, and the lenders who financed them - it does not specifically account for these phenomena either.

"Old-Keynesian" economics does better with these two specific issues. It locates the origins of economic fluctuations not in the behaviour of money, but in swings in the "animal spirits" of investors, an essentially irrational psychological factor that is said to underlie successive waves of over-optimism and excessive pessimism on their part, and in an accompanying chronic tendency for short-term "speculation" to dominate long-term "enterprise" - these are Keynes's (1936) terms - in the financial markets in which investment funds are raised. This approach, which of course echoes Lavington (1922) and Pigou (1927) on "cumulative errors of optimism and pessimism", permits "excitement" to be accompanied by price inflation, but does not require this, and it treats over-enthusiastic capital accumulation as its key feature. Even so, and the lasting importance of Keynes's contribution to out understanding of "stagnation" as a product of the monetary economy notwithstanding, this analysis of "excitement" seems better adapted to rationalizing its characteristics ex post than at explaining them ex ante, as I have argued at greater length in Laidler (2010). ${ }^{19}$ This "old-Keynesian" way of dealing with the facts of instability in the monetary economy that the Monetarist alternative neglects might, of course, turn out to be the best available, and given what we have said above about the incentives inherent in a monetary economy for agents to act on the basis of less than fully rational expectations, we cannot quite rule this out. But there remain other possibilities worth considering.

\footnotetext{
19 And it also leads rather too quickly for comfort to proposals for "the introduction of a substantial Government transfer tax on all transactions" (Keynes 1936, p. 160) in financial markets, in order to redress the balance between "speculation" and "enterprise" in their workings, as well as for "the socialization of investment" as a further means of stabilizing overall expenditure in the economy.
} 


\section{Hayek on Forced Saving in the Monetary Economy}

In the early 1930s, Keynes's most prominent critic was Friedrich von Hayek, but though antagonists over most issues, these two were always in complete agreement about the overall theme of this lecture: namely, that economic instability must be understood as a property specific to the monetary economy. Unlike his later self, the Hayek of this period was a devotee of and a notable contributor to static Walras-inspired general equilibrium theory, then so popular among non-Marxist continental European economists. ${ }^{20}$ However, in his view

Trade Cycle theory cannot aim at the adaptation of the adjusting mechanism of static theory to a special case; this scheme of explanation must itself be extended so as to explain how. . .discrepancies between supply and demand can ... arise. The obvious, and (to my mind) the only possible way ... is to explain the difference between the course of events described by static theory ... and the actual course of events, by the fact that, with the introduction of money (or strictly speaking with the introduction of indirect exchange), a new determining cause is introduced." (Hayek, 1933. p. 44)

Even so, he was critical of earlier theories of the trade cycle in what we would now call the Monetarist tradition. ${ }^{21}$

Monetary theories of the Trade Cycle succeeded in giving prominence to the right questions and, in many cases, made important contributions towards their solution; but the reason why an unassailable solution has not yet been put forward seems to reside in the fact that all the adherents of the monetary theory of the Trade Cycle have sought an explanation either exclusively or predominantly in the superficial phenomena of changes in the value of money, while failing to pursue the far more profound and fundamental effects of the process by which money is introduced into the economic system, as distinct from its effects on prices in general. Nor did they follow up the consequences of the fundamental diversity between a money economy and the pure barter economy which is assumed in static theory." (Hayek, 1933, pp. 44-45)

The "fundamental diversity" to which Hayek here refers is the fact, of which much has already been made above, that exchange in a monetary economy takes place through a series of bilateral trades mediated by money, while the process by which money is introduced into the system to whose effects he calls attention arises from its being the liability of a banking system, whose activities in credit markets lead to the creation of money as their by-product. Hayek started from the essentially Wicksellian (.e.g. 1898) proposition that, so long as the banking system maintained the rate of interest at a value at which the plans of households for the time path of consumption matched those of firm for the time path of production, the monetary economy would operate "as if" it were an equilibrium system, but that if the banking system set the wrong "market" rate, and in particular set it too low, then things would begin to go amiss.

\footnotetext{
${ }^{20}$ The common Walrasian starting point of the cycle theories of Hayek and Lucas prompted me to flirt for a while with the label "neo-Austrian" as an alternative to "New-classical" for the latter. See for example, my essay on "The Austrians and the Stockholm School: two failures in the development of modern macroeconomics?" (Laidler 2004, Ch. 9) This was misleading, as Axel Leijonhufvud quickly convinced me by pointing out in his (1991) comment on this paper that at least the Austrians understood that things could go badly wrong in an economy that had nevertheless started out in equilibrium.

${ }^{21}$ Including Keynes's own contribution to this line of work, the Treatise on Money (1930). See Hayek's two part (Hayek 193 1-1932) review of that work.
} 


\section{Forced Saving as Trading at a False Price}

Specifically, the emergence of a particular example of a false price, namely "too low" a market rate of interest, would misleadingly signal to investors that households had decided to shift their pattern of consumption over time away from the present and towards the future, while the willingness of banks to make loans at this rate would simultaneously allow them to acquire money with which to bid successfully against households for the resources required to set new and apparently profitable projects in motion. Households would thus be "forced" to relinquish these resources, and hence to "save", even though they had formed no inclination to buy the goods that the new investment projects, once completed, would produce. ${ }^{22}$

The money thus injected into circulation might, to be sure, also have effects on the price level, as standard monetary theories predicted, but these were of secondary importance compared to the real mismatches developing between households' plans for future consumption, and firms' plans to satisfy them. These disequilibria would continue to grow so long as the market rate of interest remained "too low", and the longer it did so, the greater would be the eventual dislocation of the real economy when the resulting investments were finally revealed to have been unprofitable mistakes, and the more violent also the associated instability in the financial system that had financed them as borrowers found themselves unable to meet their obligations.. It is hard to see how such mistakes on the part of individuals with their consequent dislocations of market mechanisms could persist long enough to do much harm in a world where plans are based on fully informed rational expectations, of course, but as we have already argued, such expectations are unlikely to characterize a monetary economy.

The phenomenon of "forced saving" had been recognized from time to time for more than a century before Hayek and his fellow Austrians made it the centre-piece of a theory which, in the early 1930s looked for a while as if it would sweep the field as an explanation of economic instability ${ }^{23}$ This incipient "Austrian" revolution eventually failed in the face of competition from the "old-Keynesian" alternative, but its eclipse was in some respects regrettable. Though it did not offer any satisfactory account of why chronic unemployment was a feature of "stagnation", and, crucial to its success, that old-Keynesian rival did, what Roger Garrison (2001) later called Hayek's "theory of the inflationary boom", based on forced saving, provided a perhaps more attractive explanation of the emergence of "excitement" and "convulsion", inasmuch as its pivotal mechanism relied not on irrational swings in animal spirits, but rather to a dislocation in the allocation of resources over time created by the responses of rational agents to inappropriate information and incentives conveyed to them by a falsely low value for the rate of interest.

The interest rate's tendency to settle at false values from time to time in a money economy also needs to be explained, of course, and Austrians have often attributed this to the proclivity of state-run central banks to indulge in inflationary low-interest rate policies - it is no

\footnotetext{
${ }^{22}$ For the sake of brevity, the description of "forced saving" given here is, to say the least, basic, and does not do full justice to the subtlety of Hayek's own treatment of the idea in Prices and Production (1931). Note also, that Hayek (1933), the work cited here, is in fact an English translation of a German monograph whose first version appeared in 1928, before Hayek had fully developed his analysis of the cycle.

${ }^{23}$ Its first appearance in print seems to have been due to Henry Thornton (1802). Hayek (1932) is still the best account of the idea's history. Note that the essentials of what came to be called the Austrian theory of the cycle were developed by Ludwig von Mises as early as (1912), and he in turn was dealing with problems posed by Wicksell's (1898) seminal book, Interest and Prices
} 
accident that the later Hayek would propose The Denationalization of Money (1976) - and in many times and places such an explanation has fitted only too well. But it doesn't fit the facts everywhere - those generated by the typical $19^{\text {th }}$ century cycle for example, either in the Britain with which our cartoonist was familiar, where the central bank was privately owned, or the United States which didn't even acquire a central bank until 1913 - and in any event, a shortfall of the rate of interest from its market-clearing value can emerge in many other ways ${ }^{24}$. For example, Keynes's sometime student, collaborator and eventual critic, Dennis Robertson (1926) noted both the ubiquity of technical innovations and their capacity to raise real rates of return in the industries where they occurred, and stressed that it was the role of a well functioning banking system to reallocate the current flow of households' savings towards these, with what he termed "appropriate" fluctuations in output and prices being likely to accompany the process. But he also suggested that bank lending to expanding sectors where rates of return were unusually high could all too easily be overdone, leading to excessive investment financed by forced saving, and super-imposing "inappropriate" fluctuations in output and prices upon the "appropriate" ones ${ }^{25}$.

There is, in any event, no reason to insist on the same cause for every instance of the emergence of a too low market interest rate that then gives rise to forced saving. For example, the recent crisis seems to have been preceded, not by innovations in production driven by technical change, but by innovations in the financial sector that distorted the links between policy interest rates and those faced by certain classes of borrowers. The key point is that the process of forced saving, whatever sets it going, has many attractions as an explanation of those transitions from "prosperity" to "excitement" and thence to "convulsion" that precede "stagnation".

To begin with, forced saving provides a particular instance of the trading at false prices that is endemic to the monetary economy, the false prices in question in this instance being the rates of interest ruling in the market where the allocation of resources over time is coordinated, the very same market in which Keynes located the roots of "stagnation". Furthermore forced saving works exactly on that margin between the monetary system and the real economy to which our cartoonist drew attention in the late 1850s when he depicted "excitement", and it also explains the tendencies of crises both to leave unwanted capital in their wake as well as to create associated solvency as well as liquidity problems for the financial institutions which financed its creation. Finally, it explains why crises are usually but not always heralded by bouts of general price inflation. To adopt today's terminology, forced saving is a consequence of the unanticipated creation of credit by financial institutions and within limits, as both the Austrians and Robertson knew, it can take place without inflation because, though credit creation entails the creation of money as a by-product, a growing economy can absorb a certain amount of monetary expansion

\footnotetext{
${ }^{24}$ This is not to say that the $19^{\text {th }}$ century Bank of England did not sometimes set its discount rate at too low, and hence inflationary, levels, because it did. However, the causes here had more to do with a deficient understanding of the mechanisms of monetary policy on the part of its directors than with any conscious desire to maximize seigniorage on behalf of government.

25 In (1915) Robertson had approached the explanation of Industrial Fluctuation from the point of view of what is often called the Marx-Schumpeter tradition in business cycle theory, stressing the uneven pace of technical change as itself being the cycle's source. In the 1920s, with Keynes's encouragement, he began to integrate monetary factors into his analysis, without giving up his appreciation of the importance of technical change. He thus has a strong claim, as Charles Goodhart (1992) pointed out, to be viewed as an early exponent of what is now termed "real business cycle theory". However, unlike modern exponents of that theory, he did not confine his analysis to states of equilibrium.
} 
without inflationary pressures. It is striking that this is what Robertson, writing in (1928, pp. 9192), thought was happening in the United States just before the Depression, where a boom was clearly in progress but the price level was not rising. Similar arguments can, perhaps be made about Japan in the late 1980s and the United States more recently.

\section{Monetary Policy for the Monetary Economy}

If being aware of the fact that the market economy is really a monetary economy helps us to understand economic crises such as the one we have recently seen, it should surely also help us in designing policies to make the occurrence of such events less likely in the future, and to cope with their consequences when they nevertheless occur. So it surely does, but it would take another paper at least as long as this one to develop the relevant analysis in any depth, so perhaps I may be permitted to be brief, and to rely once again, as I have throughout this paper, on the wisdom of some earlier contributors to monetary economics.

\section{Controlling Money and Credit Growth}

If what we might term the Hayek-Robertson account of the transition from "prosperity" to "excitement" to "convulsion" is valid, then control over the growth rates of money and credit is crucial to reducing the chances of such processes getting out of hand. ${ }^{26}$ Since such control is also basic to the maintenance of low and stable inflation - notwithstanding the absence of this factor from those equilibrium models in terms of which inflation-targeting monetary policy has been routinely discusses in recent years - there is no fundamental conflict between the pursuit of low inflation and the maintenance of asset market stability, and, with suitable institutional adaptations, there is as much wisdom and relevance today as there ever was in Henry Thornton's (1802) advice to the Bank of England

To limit the total amount of paper issued, and to resort for this purpose, whenever the temptation to borrow is strong, to some effectual principles of restriction; in no case, however, materially to diminish the circulation, but to let it vibrate only within certain limits; to afford a slow and cautious extension of it as the general trade of the kingdom enlarges itself; to allow of some special, though temporary encrease in the event of any extra-ordinary alarm or difficulty as the best means of preventing a great demand at home for guineas and [advice relevant for today's economies only where there is reason to fear floating] to lean to the side of diminution, in the case of gold going abroad, and the general exchange continuing long unfavourable" (p.259)

Perhaps the "Great Moderation" had something to do with the fact that, for a while, many central banks were implicitly heeding this advice as they pursued their inflation targets. We should nevertheless be mindful that the Great Moderation did come to an end without serious increases in inflation preceding its collapse, and also that Thornton had in any event never offered a guarantee that stable monetary expansion would always be enough to avoid trouble: he was well aware that "some extraordinary alarm or difficulty" could always strike. We should not therefore expect even successful inflation control policies to guarantee asset market stability in all circumstances. Historical experience, not to mention the economic analysis discussed in this lecture suggests no more than that that they will help.

\footnotetext{
${ }^{26}$ It should be noted that Roberston (1926) explicitly treated forced saving as a mechanism complementary to those involving errors of optimism and pessimism, and hence presumably, "animal spirits" as well.
} 


\section{The Difficulty of Getting it Right}

Here we should also recall Dennis Robertson's admonition that "The aim of monetary policy should surely not be to prevent all fluctuations in the general price-level, but to permit those that are necessary to the establishment of appropriate alterations in output and to repress those which tend to carry the alterations in output beyond the appropriate point" (1926, p. 39). But we should also note his warnings about the extreme difficulty of getting this balance right, and his views about the implications of this difficulty for the side on which policy should then err.

"I do not feel confident that a policy which, in the pursuit of stability of prices, output and employment had nipped in the bud the British railway boom of the forties, or the American railway boom of 1869-71, or the German electrical boom of the nineties, would have been on the balance beneficial to the populations concerned (1926, p. 22)

In short, not only should we not rely on the traditional tools of monetary policy to guarantee asset market stability under all circumstances, but we should not work so hard at trying to make them do so that we jeopardize other goals. Asset markets exist, after all, to reallocate capital towards newly productive sectors of the economy and away from those that are flagging, and troubles with their workings all too often originate in the very relative price movements that are essential to this process, to whose control the traditional tools of monetary policy are in any event badly adapted. This is where regulation might help, if of course we knew how to get that right, a matter that must be discussed on some other occasion. In the meanwhile, it would be wise for today's central banks to remain always prepared to follow Thornton's advice about supplying the modern equivalent of guineas to meet the sudden demands for liquidity that accompany "convulsion" and of which Mill made so much, and to act as lenders of last resort. And if such measures fail to prevent the onset of stagnation, then, as I have already argued in this lecture, the great strength of old-Keynesian economics lies in what it has to say about this state of affairs. My own preference on the policy front here would be to follow the Keynes of the Tract on Monetary Reform and the Treatise of Money, rather than of The General Theory, not to mention among others, Milton Friedman (e.g. Friedman and Schwartz 1963), whom Lucas (2004) correctly identified as being intellectually closer to Keynes than to modern dynamic general equilibrium modelers, and to put more weight on monetary than fiscal remedies, but like financial system regulation, this too is a topic for another time.

\section{A Final Word}

To the objection that the application of old-Keynesian policies to an economy that has passed through "convulsion" into "stagnation" amounts to prolonging the measures that in the first place created the "excitement" that led up to it all, Lionel Robbins (1971) recantation of his (1934) deployment of this same, very Austrian, objection may be offered in rebuttal

"Assuming that the original diagnosis of excessive financial ease and mistaken real investment was correct ... to treat what developed subsequently in the way which I then [1934] thought valid was an unsuitable as denying blankets and stimulus to a drunk who has fallen into an icy pond on the ground that his original problem was overheating" (p.154)

Or to put matters in the language deployed in this lecture, although "excitement", "convulsion" and "stagnation" are all manifestations of the damaging effects on the monetary economy of the trading at false prices that equilibrium modeling assumes to be impossible, the false nature of the prices in question changes as the economy moves through these states, their effects on real activity therefore change, and those effects require changing remedies. 


\section{References}

Akerlof G. and R. Shiller (2009) Animal Spirits, Princeton, N.J. Princeton University Press

Anonymous (1858) The Overstone theory of trade, in The Money Bag. Literature, Politics, Finance, London, Oakley, 111-115

Ascheim, J. and G. Tavlas (1991) Doctrinal foundations of monetary economics - a review essay. Journal of Monetary Economics 28, 501-510

Benassy, J. P. (1993) Non-clearing markets: microeconomic concepts and macroeconomic applications, Journal of Economic Literature 31 (June) 732-761

Besomi, D. (2011) Graphical representations of Overstone's cycle of trade (mimeo)

Clower, R. W. (1965) The Keynesian counter-revolution: a theoretical appraisal, in F. H. Hahn \& F.R. Brechling (eds.) The Theory of Interest Rates London, Macmillan

Fisher, I. (1911) The Purchasing Power of Money New York, Macmillan

Friedman, M. and A. J. Schwartz (1963) Money and business cycles Review of Economics and Statistics 45 (Feb.) 32-63

Garrison, R. (2001) Time and Money London and New York, Routledge

Goodhart, C. A. E. (1992) Robertson and the real business cycle, in j. R. Presley (ed.) Essays on Robertsonian Economics London, Macmillan

Hahn, F. H. (1965) On some problems in proving the existence of equilibrium in a monetary economy in F. H. Hahn and F.R Brechling (eds.) The theory of Interest Rates London, Macmillan

Hawtrey, R. G. (1913) Good and Bad Trade London, Constable

Hayek, F. A. von (1931) Price and Production London, Routledge

(1931-32) Reflections on the Pure Theory of Money of Mr. J. M. Keynes, Economica 11 (Aug) \& 12, (Feb) 270-295 \& 22-44.

(1932) A note on the development of the doctrine of forced saving, Quqrtyerly Journal of Economics 47 (Nov.) 123-133

(1933) Monetary theory and the Trade Cycle, (tr. N. Kaldor \& H. Croome), London, Routledge and Kegan Paul

(1976) Denationalizing Money, London, IEA 
Howitt, P. W. (1978) The limits to stability of a full employment equilibrium, Scandinavian Journal of Economics, (rpr. in P. W. Howitt, The Keynesian Recovery and other Essays, Hemel Hempstead, Philip Allan, 1990)

Keynes, J. M. (1923) A Tract of Monetary Reform London, Macmillan (1930) A Treatise on Money (2 vols.) London, Macmillan

(1936) The General Theory of Employment, Interest and Money, London, Macmillan

Kindleberger, C. (1978) Manias, Panics and Crashes: a History of financial Crises, New York, Basic Books, $\left(5^{\text {th }} \mathrm{ed}\right.$, New York, wiley, 2005)

Kiyotaki N. and R. Wright (1989) On money as a medium of exchange, Journal of Political Economy

Kocherlakota, N. (1998) Money is memory Journal of Economic Theory 81 (Aug.) 232-251

Krugman, P. (2009) How did economists get it so wrong? New York Times, Sept. 6th

Laidler, D. (1988) Taking money seriously, Canadian Journal of Economics 21 (Nov.) 687-713)

--------- (1999) Fabricating the Keynesian Revolution: Studies in the Interwar Literature on Money, the Cycle, and Unemployment Cambridge, Cambridge University Press

(2004) Macroeconomics in Retrospect: the Selected Essays of David Laidler Cheltenham, Edward Elgar

(2006) Grasping the nettles: clearing the path to financial services reform in Canada, Commentary 238, Toronto, C. D. Howe Institute

(2010) Lucas, Keynes and the Crisis Journal of the History of Economic Thought 32 (March) 39-62

Lavington, F. (1922) The Trade Cycle London, P. S. King and Son.

Leijonhufvud A (1968) On Keynesian Economics and the Economics of Keynes, Oxford, Oxford University Press

(1973) Effective demand failures, Swedish Journal of Economics (rpr. in A. Leijonhufvud, Information and Co-ordination Oxford Oxford University Press, 1981)

(1991) Comment in L, Jonung ed. The Stockhom School of Economics Revisited Cambridge, Cambridge University Press 
Lucas. R. E. Jr (1996) Nobel Lecture: monetary neutrality, Journal of Political Economy 104 (Aug.) 661-682

(2004) My Keynesian education in M. deVroey \& K. Hoover eds. The IS-LM Model: Its Rise, Fall and Strange Persistence, Annual Supplement to Vol. 36 of History of Political Economy, Durham, N. C., Duke University Press

(2009) Economics focus: in defence of the dismal science, The Economist (Aug. $8^{\text {th }}$ ) p.87

Marshall, A. (1871) Money, in The Early Economic Writings of Alfred Marshall (ed. J. Whitaker), London, Macmillan 1975

- (1887) Remedies for fluctuations in general prices, Contemporary Review, (March) \& M. P. Marshall (1879) The Economics of Industry London, Macmillan

Meltzer, A. H. (2003) A History of the Federal Reserve Vol. 1, Chicago, University of Chicago Press

Mill, J. S. (1844) On the influence of consumption on production, in Some Unsettled Questions of Political Economy, London, (rpr. Clifton N. J., Augustus Kelley, 1974)

(1848) Principles of Political Economy, with Some of Their Applications to Social Philosophy, London ( $7^{\text {th }}(1871)$ ed. rpr. ed. J. M. Robson, Toreonto, University of Toronto Press, 1965)

Minsky, H. P. (1982) Can "It" Happen Again? Essays on Instability and Finance, Arnonk, N. Y. M. E. Sharpe

Mises, L. von (1912) Theorie des Geldes und der Umlaufsmittel, Munich, Dunker \& Humblot

Overstone, Lord, (Samuel Jones-Loyd) (1971) The Correspondence of Lord Overstone 3 Vols. (ed. D. P. O'Brien, Cambridge, Cambridge University Press)

Patinkin, D. (1957) Money, Interest and Prices Evanston, Row Petersen

------------ (1982) Anticipations of the General Theory? And Other Essays on Keynes.

Chicago, University of Chicago Press

Pigou, A. C. (1913) Unemployment London, Williams \& Norgate (1927) Industrial Fluctuations, London, Macmillan

Robbins, L. C. (1934) The Great Depression London, Macmillan 
------------- (1971) Autobiography of an Economist London, Macmillan

Robertson, D. H. (1915) Industrial Fluctuation London, P.S. King \& Son

------------------- (1926) Banking Policy and the Price Level London, Macmillan (1928) Money $3^{\text {rd }}$. ed., London, Nisbet

Smith, A. (1776) An Inquiry into The Nature and Causes of the Wealth of Nations, London (R.H. Campbell and A. Skinner, eds, Oxford, Oxford Universaity Press, 1976)

Thornton, H. (1802) An Enquiry into the Nature and Effects of the Paper Credit of Great Britain,(rpr. with an Introduction by F. A. von Hayek, London Allen and Unwin, 1939)

Walras, L. (1874) Elements of Pure Economics Lausanne (tr. William Jaffe, Homewood Ill. Richard Irwin for the AEA and RES, 1954)

(1886) La Theorie de la Monnaie Lausanne, Corbaz

Wicksell, K. (1898) Interest and Prices (tr. By R. F. Kahn, London, Macmillan for the Royal Economic Society, 1936)

Woodford, M. (2003) Interest and Prices Princeton, Princeton University Press 